\title{
Dihydropyranoflavones from Pongamia pinnata
}

\author{
Hao Yin, ${ }^{*, a}$ Si Zhang, ${ }^{*, a, b}$ Jun $\mathrm{Wu}^{a}$ and Haihan Nan ${ }^{a}$ \\ ${ }^{a}$ Guangdong Key Laboratory of Marine Materia Medica, South China Sea Institute of Oceanology, \\ Chinese Academy of Sciences, 164 West Xingang Road, Guangzhou, 510301, P.R. China \\ ${ }^{b}$ Hainan Key Lab of Tropical Marine Biotechnology, Chinese Academy of Science, Sanya, 572000, P.R. China
}

Das cascas do caule de Pongamia pinnata foram isolados dois novos compostos, 3-metoxi(3",4"-diidro- 3"-hidroxi-4"-acetoxi)-2", 2"-dimetilpirano-(7,8:5",6")-flavona e 3-metoxi-(3",4"diidro-4" - hidroxi-3"-acetoxi)-2",2"-dimetilpirano-(7,8:5",6")-flavona, juntamente com seis compostos conhecidos, óxido de cariofileno, obovatachalcona, 8-hidroxi-6-metoxi-3-pentil-1Hisocromeno-1-ona, 6,7,2,2-dimetilcromono-8, $\gamma, \gamma$-dimetilalilflavonona, isolonchocarpin, ovaliflavanona A. Suas estruturas foram determinadas a partir da interpretação de dados espectroscópicos.

From the stem bark of Pongamia pinnata, two new compounds, 3-methoxy-(3",4"-dihydro- 3"hydroxy-4"-acetoxy)-2",2"-dimethylpyrano-(7,8:5",6")-flavone and 3-methoxy-(3",4"-dihydro-4"hydroxy-3"-acetoxy)-2",2"-dimethylpyrano-(7,8:5",6")-flavone, were isolated, along with six known compounds, caryophyllene oxide, obovatachalcone, 8-hydroxy-6-methoxy-3-pentyl-1H-isochromen1-one, 6,7,2,2-dimethylchromono-8, $\gamma, \gamma$-dimethylallylflavanone, isolonchocarpin, ovaliflavanone A. Their structures were determined on the basis of the spectroscopic data interpretation.

Keywords: Pongamia pinnata, prenylated flavonoids, flavone

\section{Introduction}

Pongamia pinnata (Linn) Pierre (Leguminosae, Papilionaceac; synonym, Pongamia glabra Vent), the only one species of genus Pongamia, is a medium sized glabrous tree, grows in the littoral regions of South Eastern Asia and Australia. All parts of the plant have been used as crude drug for the treatment of tumors, piles, skin diseases, wounds and ulcers. ${ }^{1}$ Extracts of the plant possess significant anti-diarrhoeal, anti-fungal, anti-plasmodial, antiulcerogenic, anti-inflammatory, and analgesic activities. ${ }^{2}$ Previous phytochemical investigation of this plant indicated the presence of abounding prenylated flavonoids such as furanoflavones, furanoflavonols, chromenoflavones, furanochalcones, and pyranochalcones. ${ }^{3}$ In this paper, we reported the isolation and identification of two new flavones $(\mathbf{1}, \mathbf{2})$ from the stem bark of Pongamia pinnata.

\section{Results and Discussion}

The EtOH extract of Pongmia pinnata stem bark was submitted to successive chromatography, affording two

*e-mail: yin_hao_gz@hotmail.com new prenylated flavones $\mathbf{1}$ and $\mathbf{2}$ (Figure 1) along with six known compounds 3-8.

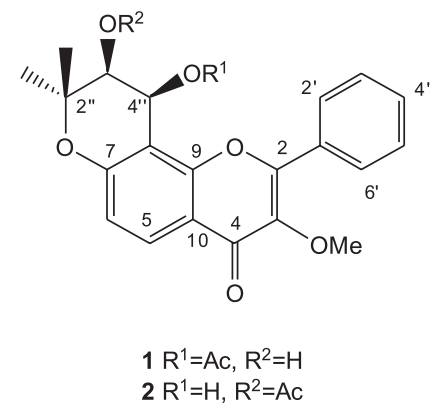

Figure 1. Structures of compounds $\mathbf{1}$ and 2.

Compound 1, a white powder, gave a molecular ion $\left[\mathrm{M}^{+}\right]$at $m / z 410.13657$ in the HREIMS, indicating a molecular formula $\mathrm{C}_{23} \mathrm{H}_{22} \mathrm{O}_{7}$ (calc. 410.13655). Together with HMQC spectra, the $1 \mathrm{D}$ NMR $\left({ }^{13} \mathrm{C},{ }^{1} \mathrm{H}\right.$ and DEPT, Table 1) spectra of compound $\mathbf{1}$ displayed resonances for one conjugated ketone $\left(\delta_{\mathrm{C}} 173.4, \mathrm{C}-4\right)$, a pair of orthocoupling aromatic protons $\left(\delta_{\mathrm{H}} 7.98,1 \mathrm{H}, \mathrm{d}, J 8.9 \mathrm{~Hz}, \mathrm{H}-5\right.$; $\left.\delta_{\mathrm{H}} 6.96,1 \mathrm{H}, \mathrm{d}, J 8.9 \mathrm{~Hz}, \mathrm{H}-6\right)$, a monosubstituted aromatic ring $\left(\delta_{\mathrm{H}} 7.95,2 \mathrm{H}, \mathrm{m}, \mathrm{H}-2^{\prime}, 6^{\prime} ; \delta_{\mathrm{H}} 7.55,3 \mathrm{H}, \mathrm{m}, \mathrm{H}-3^{\prime}, 4^{\prime}\right.$, $\left.5^{\prime}\right)$, two oxygenated methines $\left(\delta_{\mathrm{H}} 3.93,1 \mathrm{H}, \mathrm{d}, J 4.8 \mathrm{~Hz}\right.$, H-3"; $\delta_{\mathrm{C}} 69.3, \mathrm{C}-3^{\prime \prime} ; \delta_{\mathrm{H}} 6.46,1 \mathrm{H}, \mathrm{d}, J 4.8 \mathrm{~Hz}$, 
$\left.\mathrm{H}-4^{\prime \prime} ; \delta_{\mathrm{C}} 63.2, \mathrm{C}-4^{\prime \prime}\right)$, a acetoxy group $\left(\delta_{\mathrm{H}} 1.90,3 \mathrm{H}, \mathrm{s}, \delta_{\mathrm{C}}\right.$ $170.0, \delta_{\mathrm{C}} 21.0$, OAc-4"), two methyls $\left(\delta_{\mathrm{H}} 1.41,3 \mathrm{H}, \mathrm{s}, \delta_{\mathrm{C}}\right.$ 26.4, $\left.\mathrm{Me}_{1}-2^{\prime \prime} ; \delta_{\mathrm{H}} 1.38,3 \mathrm{H}, \mathrm{s}, \delta_{\mathrm{C}} 21.3, \mathrm{Me}_{2}-2^{\prime \prime}\right)$, a methoxy group $\left(\delta_{\mathrm{H}} 3.81,3 \mathrm{H}, \mathrm{s}, \delta_{\mathrm{C}} 60.1, \mathrm{OCH}_{3}-3\right)$, and an oxygenated quaternary carbon $\left(\delta_{\mathrm{C}} 79.5, \mathrm{C}-2^{\prime \prime}\right)$. With great similarity to those of 5-methoxy-(3",4"-dihydro-3",4"diacetoxy)-2", $2^{\prime \prime}$-dimethylpyrano-(7,8:5", $\left.6^{\prime \prime}\right)$-flavone, ${ }^{4}$ these 1D NMR data suggested that compound $\mathbf{1}$ was a flavone with a acetylated dihydropyrano unit. In HMBC spectra, the correlation between $\mathrm{H}-5\left(\delta_{\mathrm{H}} 7.98,1 \mathrm{H}, \mathrm{d}, J\right.$ $8.9 \mathrm{~Hz})$ and $\mathrm{C}-4\left(\delta_{\mathrm{C}} 173.4\right)$ indicated that the ring A was unsubstituted at the C-5 and C-6 position. The observed HMBC correlations from H-3" $\left(\delta_{\mathrm{H}} 3.93,1 \mathrm{H}, \mathrm{d}, J 4.8 \mathrm{~Hz}\right.$, $\left.\mathrm{H}-3^{\prime \prime}\right)$ to $\mathrm{C}-8\left(\delta_{\mathrm{C}} 108.2\right)$, from $\mathrm{H}-4 "{ }^{\prime \prime}\left(\delta_{\mathrm{H}} 6.46,1 \mathrm{H}, \mathrm{d}, J\right.$ $4.8 \mathrm{~Hz})$ to $\mathrm{C}-8\left(\delta_{\mathrm{C}} 108.2\right), \mathrm{C}-7\left(\delta_{\mathrm{C}} 158.3\right)$, and $\mathrm{C}-9\left(\delta_{\mathrm{C}} 155.0\right)$ suggested that the dihydropyran ring is attached to A ring at C-7(oxygenated) and C-8 postion. The location of the acetoxy group at C-4" were established by HMBC correlations from protons of $\mathrm{Me}_{1}-2^{\prime \prime}, \mathrm{Me}_{2}-2^{\prime \prime}$ to C-3", and from $\mathrm{H}-4^{\prime \prime}$ to the carbonyl of OAc- 4 ". The location of the methoxyl group $\left(\delta_{\mathrm{H}} 3.81\right)$ at $\mathrm{C}-3$ was revealed by the HMBC correlation from the protons of methoxy group to C-3 $\left(\delta_{\mathrm{C}}\right.$ 141.1). The substitution of a hydroxyl group at $\mathrm{C}-3^{\prime \prime}\left(\delta_{\mathrm{C}} 72.9\right)$ was enclosed by chemical shift of C-3" in ${ }^{13} \mathrm{C}$ NMR spectra and the HREIMS data. The molecular structure of $\mathbf{1}$ contained two chiral carbon atoms, and the relative configuration of $\mathrm{C}-3^{\prime \prime}$ and $\mathrm{C}-4$ " was determined as cis on the basis of coupling constant $J_{3^{\prime \prime}, 4^{\prime \prime}}(4.8 \mathrm{~Hz})$ and the difference $(0.03 \mathrm{ppm})$ in the methyl proton signals at $\delta_{\mathrm{H}} 1.41$ and $\delta_{\mathrm{H}} 1.38$ of the 2 "-gem dimethyl group. ${ }^{5}$ Accordingly, compound $\mathbf{1}$ was characterized as 3methoxy-(3", 4"-dihydro-3"-hydroxy-4"-acetoxy)-2",2"dimethylpyrano-(7,8:5",6")-flavone.

Compound 2, a white powder, gave a molecular ion $\left[\mathrm{M}^{+}\right]$at $m / z 410.13665$ in the HREIMS, corresponding to the molecular formula $\mathrm{C}_{23} \mathrm{H}_{22} \mathrm{O}_{7}$ (calc. 410.13655). The NMR spectral data of $\mathbf{2}$ (Table 1) were closely comparable to those of compound $\mathbf{1}$, with the only difference being due to the position of the acetoxy group $\left(\delta_{\mathrm{H}} 2.13,3 \mathrm{H}, \mathrm{s}\right.$, $\delta_{\mathrm{C}} 170.5, \delta_{\mathrm{C}} 21.3$, OAc-3") and hydroxyl group on the pyran ring. In HMBC spectra, the observed correlations from protons of $\mathrm{Me}_{1}-2^{\prime \prime}\left(\delta_{\mathrm{H}} 1.41,3 \mathrm{H}, \mathrm{s}\right), \mathrm{Me}_{2}-2^{\prime \prime}\left(\delta_{\mathrm{H}} 1.35\right.$, $3 \mathrm{H}, \mathrm{s})$ to $\mathrm{C}-3^{\prime \prime}\left(\delta_{\mathrm{C}} 72.9\right)$, and from $\mathrm{H}-3^{\prime \prime}\left(\delta_{\mathrm{H}} 5.06,1 \mathrm{H}, \mathrm{d}, J\right.$ $4.8 \mathrm{~Hz}$ ) to the carbonyl of acetoxyl group suggested the acetoxy group to be located on C-3" position. Further analysis of the NMR and MS spectra of compound 2 indicated the presence of the hydroxyl group at C-4" position. The coupling constant $J_{3^{\prime \prime}, 4^{\prime \prime}}$ was $4.8 \mathrm{~Hz}$ and the chemical shift difference of gem-dimethyl signals was 0.06 $\mathrm{ppm}$ in ${ }^{1} \mathrm{H}$ NMR spectrum. This evidence suggested that the relative configuration of compound $\mathbf{2}$ was cis-form.
Thus compound 2 was characterized as 3-methoxy-(3",4"dihydro-4"-hydroxy-3"-acetoxy)-2", 2"-dimethylpyrano(7,8:5",6")-flavone.

Additionally 6 known compounds, caryophyllene oxide (3), ${ }^{6}$ obovatachalcone (4), ${ }^{7} 8$-hydroxy-6-methoxy-3-pentyl1H-isochromen-1-one (5), ${ }^{8} 6,7,2,2$-dimethylchromono- $8, \gamma, \gamma$ -dimethylallylflavanone (6), ${ }^{9}$ isolonchocarpin (7), ${ }^{10}$ ovaliflavanone A (8), ${ }^{11}$ were isolated from this plant and their structures elucidated by comparing their spectroscopic data with those reported in the literature. Compounds $\mathbf{3 , 5}$, $\mathbf{6}$ and $\mathbf{8}$ were isolated for the first time from this plant.

\section{Experimental}

\section{General}

Optical rotation were measured with a Jasco 1020 polarimeter. NMR spectra were obtained on a Bruker AVANCE 500 spectrometer (500 MHz for ${ }^{1} \mathrm{H}$ NMR, 125 $\mathrm{MHz}$ for ${ }^{13} \mathrm{C}$ NMR). EIMS and HREIMS spectra were recorded on a Finnigan MAT TSQ 700 mass spectrometer. UV spectra were obtained in a Beckman DU-640 UV spectrophotometer. A Waters Nova-pack HR C18 column $(19 \times 300 \mathrm{~mm})$ was used for semipreparative HPLC, along with Waters 600E Multisolvent Delivery System and a Waters 996 Photodiode Array Detector.

\section{Plant material}

The material investigated were stem bark of Pongamia pinnata collected in October 2002 from Hainan Province, southern China. The material was identified by Professor Si Zhang, Guangdong Key Laboratory of Marine Materia Medica, South China Sea Institute of Oceanology, Chinese Academy of Sciences. A voucher specimen is deposited at the herbarium of the South China Sea Institute of Oceanology (No. GKLMMM005).

\section{Extraction and isolation}

The dryied and powdered stem bark $(6 \mathrm{~kg})$ of Pongamia pinnata was extracted with $95 \% \mathrm{EtOH}$ three times. After evaporation of the solvents under reduced pressure, the residue $(300 \mathrm{~g})$ was then extracted successively resulting four extracts: petroleum $(80 \mathrm{~g})$, ethyl acetate $(60 \mathrm{~g}), n$ butanol $(60 \mathrm{~g})$, and aqueous $(80 \mathrm{~g})$. The petroleum extract was fractionated into 63 fractions by open $\mathrm{CC}$ over silica gel with gradient mixtures of petroleum- $\mathrm{CHCl}_{3}(6: 1)$ to $\mathrm{CHCl}_{3}$-acetone (0:1) for elution. These fractions were pooled into 17 fractions (P-1 P-17) according to their similarity on TLC. The silica gel CC of Fraction P-8 using 
Table 1. ${ }^{1} \mathrm{H},{ }^{13} \mathrm{C}$ and selected HMBC NMR data for compounds $\mathbf{1}$ and $\mathbf{2}^{\mathrm{a}}$

\begin{tabular}{|c|c|c|c|c|c|c|}
\hline \multirow[b]{2}{*}{ position } & \multicolumn{3}{|l|}{1} & \multicolumn{3}{|l|}{2} \\
\hline & $\delta_{\mathrm{H}}(J \mathrm{~Hz})$ & $\delta_{\mathrm{C}}$ & HMBC & $\delta_{\mathrm{H}}(J \mathrm{~Hz})$ & $\delta_{\mathrm{C}}$ & HMBC \\
\hline 2 & & 154.8 & & & 154.5 & \\
\hline 3 & & 141.1 & & & 141.1 & \\
\hline 4 & & 173.4 & & & 173.6 & \\
\hline 5 & $7.98(\mathrm{~d}, 8.9)$ & 127.0 & $4,7,9$ & $7.96(\mathrm{~d}, 8.9)$ & 126.2 & $4,7,9$ \\
\hline 6 & $6.96(\mathrm{~d}, 8.9)$ & 116.2 & $7,8,10$ & $6.96(\mathrm{~d}, 8.9)$ & 116.0 & $7,8,10$ \\
\hline 7 & & 158.3 & & & 157.3 & \\
\hline 8 & & 108.2 & & & 111.5 & \\
\hline 9 & & 155.0 & & & 155.4 & \\
\hline 10 & & 117.7 & & & 118.1 & \\
\hline $1^{\prime}$ & & 130.6 & & & 131.1 & \\
\hline $2^{\prime}$ & $7.95(\mathrm{~m})$ & 128.6 & & $8.20(\mathrm{~m})$ & 128.6 & \\
\hline $3^{\prime}$ & $7.55(\mathrm{~m})$ & 128.8 & & $7.57(\mathrm{~m})$ & 129.0 & \\
\hline $4^{\prime}$ & $7.55(\mathrm{~m})$ & 131.1 & & $7.57(\mathrm{~m})$ & 131.1 & \\
\hline $5^{\prime}$ & $7.55(\mathrm{~m})$ & 128.8 & & $7.57(\mathrm{~m})$ & 129.0 & \\
\hline $6^{\prime}$ & $7.95(\mathrm{~m})$ & 128.6 & & $8.20(\mathrm{~m})$ & 128.6 & \\
\hline $2^{\prime \prime}$ & & 79.5 & & & 78.1 & \\
\hline $3^{\prime \prime}$ & $3.93(\mathrm{~d}, 4.8)$ & 69.3 & $\mathrm{Me}_{1,2}-2^{\prime \prime}, 2^{\prime \prime}, 4^{\prime \prime}, 8$ & $5.06(\mathrm{~d}, 4.8)$ & 72.9 & $\mathrm{Me}_{1,2}-2^{\prime \prime}, 2^{\prime \prime}, 8, \mathrm{OAc}-3^{\prime \prime}$ \\
\hline $4^{\prime \prime}$ & $6.46(\mathrm{~d}, 4.8)$ & 63.2 & $2^{\prime \prime}, 3^{\prime \prime}, 7,8,9$, OAc-4" & $5.28(\mathrm{~d}, 4.8)$ & 59.6 & $2^{\prime \prime}, 7,8,9$ \\
\hline $\mathrm{Me}_{1}-2^{\prime \prime}$ & $1.41(\mathrm{~s})$ & 26.4 & $2^{\prime \prime}, 3^{\prime \prime}$ & $1.41(\mathrm{~s})$ & 23.2 & $2^{\prime \prime}, 3^{\prime \prime}$ \\
\hline $\mathrm{Me}_{2}-2^{\prime \prime}$ & $1.38(\mathrm{~s})$ & 21.3 & $2^{\prime \prime}, 3^{\prime \prime}$ & $1.35(\mathrm{~s})$ & 24.9 & $2^{\prime \prime}, 3^{\prime \prime}$ \\
\hline OAc-3" & & & & $2.13(\mathrm{~s})$ & $170.5 / 21.3$ & \\
\hline OAc-4" & $1.90(\mathrm{~s})$ & $170.0 / 21.0$ & & & & \\
\hline $\mathrm{OCH}_{3}-3$ & $3.81(\mathrm{~s})$ & 60.1 & 3 & $3.82(\mathrm{~s})$ & 60.0 & 3 \\
\hline
\end{tabular}

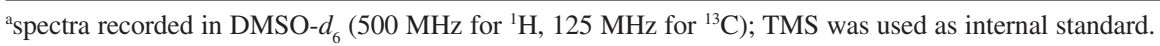

petroleum-EtOAc (3:1) afforded 7 fractions (P-8-1 to P-87). Fraction P-8-5 were purified by $\mathrm{CC}$ of PharmaciaSephadex LH-20 with $\mathrm{MeOH}-\mathrm{H}_{2} \mathrm{O}$ (95: 5) and separated by reverse phase semi-preparative HPLC (ODS column, using $\mathrm{MeOH}: \mathrm{H}_{2} \mathrm{O}(66: 34) 8 \mathrm{~mL} \mathrm{m^{-1 }}$, flow rate, UV: 254 $\mathrm{nm})$ to give compounds $1\left(1.9 \mathrm{mg}, \mathrm{t}_{\mathrm{R}}=16 \mathrm{~min}\right)$ and 2 (5.2 $\left.\mathrm{mg}, \mathrm{t}_{\mathrm{R}}=19 \mathrm{~min}\right)$. The $\mathrm{CC}$ of fraction $\mathrm{P}-6$ using petroleumEtOAc (35:1) afford 50 fractions (P-6-1 to P-6-50). The fractions P-6-10, P-6-13, P-6-18, P-6-28, P-6-35 and P-638 , purified by CC on Pharmacia-Sephadex LH-20 $\left(\mathrm{CHCl}_{3}-\right.$ $\mathrm{MeOH} 5: 1)$ or recrystallization, yield compounds 3 (113 $\mathrm{mg}), 4$ (25 mg), 5 (16 mg), 6 (9 mg), 7 (11 mg) and 8 (13 $\mathrm{mg})$, respectively.

3-methoxy-(3",4"-dihydro-3"-hydroxy-4"-acetoxy)-2",2"dimethylpyrano-(7,8:5",6")-flavone (1). $[\alpha]_{\mathrm{D}}^{25}+46.5^{\circ}$ (c $\left.0.1, \mathrm{CHCl}_{3}\right)$; UV(MeOH) $\lambda_{\max }$ / nm: 255, 316; HREIMS $m / z: 410.13657$ (calc. for $\mathrm{C}_{23} \mathrm{H}_{22} \mathrm{O}_{7} 410.13655$ ); EIMS m/z (rel. int.,\%): $410\left[\mathrm{M}^{+}\right]$(76), 409 (100), 349 (21), 335 (9), 333 (17), 297 (8), 165 (17), 163 (12); ${ }^{1} \mathrm{H}$ and ${ }^{13} \mathrm{C}$ NMR spectra data: see Table 1.

3-methoxy-(3",4"-dihydro-4"-hydroxy-3"-acetoxy)-2",2"dimethylpyrano-(7,8:5",6")-flavone (2). $[\alpha]_{\mathrm{D}}{ }^{25}+15.8^{\circ}$ (c $\left.0.1, \mathrm{CHCl}_{3}\right) ; \mathrm{UV}(\mathrm{MeOH}) \lambda_{\max } / \mathrm{nm}: 252,311$; HREIMS $m / z: 410.13667$ (calc. for $\mathrm{C}_{23} \mathrm{H}_{22} \mathrm{O}_{7}, 410.13655$ ); EIMS $\mathrm{m} / \mathrm{z}$ (rel. int.,\%): $410\left[\mathrm{M}^{+}\right]$(81), 409 (100), 349 (20), 335
(8), 333 (16), 321 (10), 297 (11), 296 (10), 295 (46), 279 (16), 165 (22), 163 (12); ${ }^{1} \mathrm{H}$ and ${ }^{13} \mathrm{C}$ NMR spectra data: see Table 1.

\section{Acknowledgments}

The authors are grateful to the financial support by the Hi-tech Research and Development Program of China (2001AA62403), Guangdong Natural Science Fundation ((2003) 11), and Research Program of Croucher Fundation. We thank Jianshe Huang and Zhihui Xiao for NMR measurements.

\section{Supplementary Information}

Supplementary Information are available free of charge at http://jbcs.sbq.org.br, as PDF file.

\section{References}

1. Tanaka, T.; Iinuma, M.; Fujii, Y.; Yuki, K.; Mizuno, M.; Phytochemistry 1992, 31, 993; Lin, P.; Journal of Xiamen University (Natural Science) 2001, 40, 592.

2. Dahanukar, S. A.; Kulkarni, R. A.; Rege, N. N.; Ind. J. Pharm. 2000, 32, 81; Shoba, F. G.; Thomas, M.; J. Ethnopharmacol. 2001, 76, 73; Simonsen, H. T.; Nordskjold, J. B.; Smitt, U. W.; Nyman, U.; Palpu, P.; Joshi, P.; Varughese, G.; J. Ethnopharmacol. 2001, 
74, 195; Srinivasan, K.; Muruganandan, S.; Lal, J.; Chandra, S.; Tandan, S. K.; Prakash, V. R.; J. Ethnopharmacol. 2001, 78, 151; Misra, S. K. ; Sahu, K. C.; Ind. J. Pharm. 1977, 9, 269.

3. Yin, H.; Zhang, S.; Wu, J.; Z. Naturforsch., B 2005, 60, 356; Yadav, P. P.; Ahmad, G. A.; Maurya, R.; Phytochemistry 2004, $65,439$.

4. Carcache-Blanco, E. J.; Kang, Y. H.; Park, E. J.; Su, B.-N.; Kardono, L. B. S.; Riswan, S; Fong, H. H. S.; Pezzuto, J. M.; Kinghorn, A. D.; J. Nat. Prod. 2003, 66, 1197; to Additions and Corrections, see reference: Carcache-Blanco, E. J., Kang, Y. H.; Park, E. J.; Su, B. N.; Kardono, L. B. S.; Riswan, S.; Fong, H. H. S.; Pezzuto, J. M.; Kinghorn, A. D.; J. Nat. Prod. 2004, 67, 126.
5. Lemmich, J.; Lemmich, E.; Nielsen, B. E.; Acta Chem. Scand. 1966, 12, 2497; Kong, L. Y.; Li, Y.; Min, D. Z.; Li, X.; Zhu, T. R.; Phytochemistry 1996, 41, 1423.

6. Oliveira Chaves, M. C.; de Oliveira Santos, B. V.; Fitoterapia 2002, 73, 547.

7. Pathak, V. P.; Saini, T. R.; Khanna, R. N.; Phytochemistry 1983, 22, 1303.

8. Kojjoa, A.; Gonzalez, M. J. T. G.; Pinto, M. M. M.; Planta Med. 1991, 57, 575.

9. Sultana, S.; Ilyas, M.; Phytochemistry 1986, 25, 963.

10. Nascimento, M. C. D; Mores, W. B.; Phytochemistry 1972, 11, 3023.

11. Gupta, R. K.; Krishnamurti, M.; Phytochemistry 1976, 15, 832.

Received: November 20, 2005

Published on the web: August 1, 2006 


\section{Dihydropyranoflavones from Pongamia pinnata}

\section{Hao Yin, ${ }^{*, a}$ Si Zhang, ${ }^{*, a, b}$ Jun $\mathrm{Wu}^{a}$ and Haihan Nan ${ }^{a}$}

${ }^{a}$ Guangdong Key Laboratory of Marine Materia Medica, South China Sea Institute of Oceanology, Chinese Academy of Sciences, 164 West Xingang Road, Guangzhou, 510301, P.R. China

${ }^{b}$ Hainan Key Lab of Tropical Marine Biotechnology, Chinese Academy of Science, Sanya, 572000, P.R. China

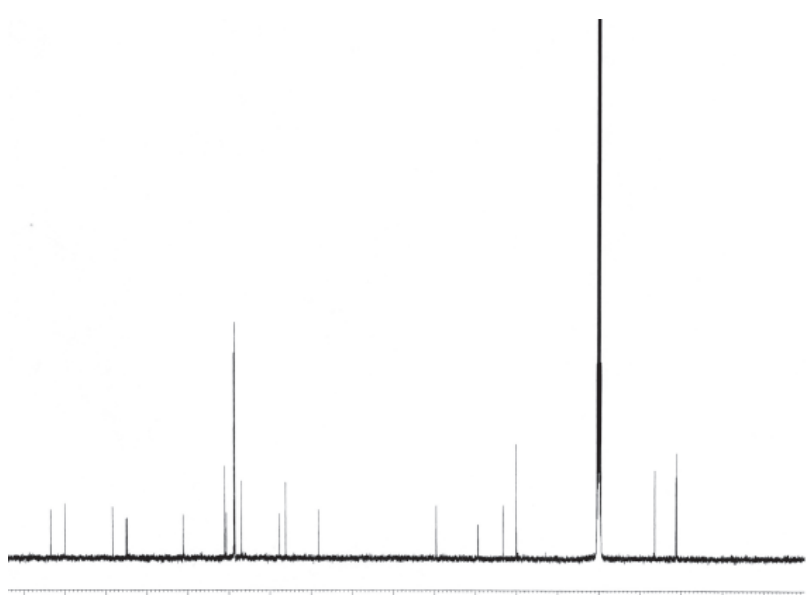

\begin{tabular}{llllllllllllllllllll}
\hline 80 & 170 & 160 & 150 & 140 & 130 & 120 & 110 & 100 & 90 & 80 & 70 & 60 & 50 & 40 & 30 & 20 & 10 & $\mathrm{ppm}$
\end{tabular}

Figure S1. ${ }^{13} \mathrm{C}$ NMR spectra of 1 .

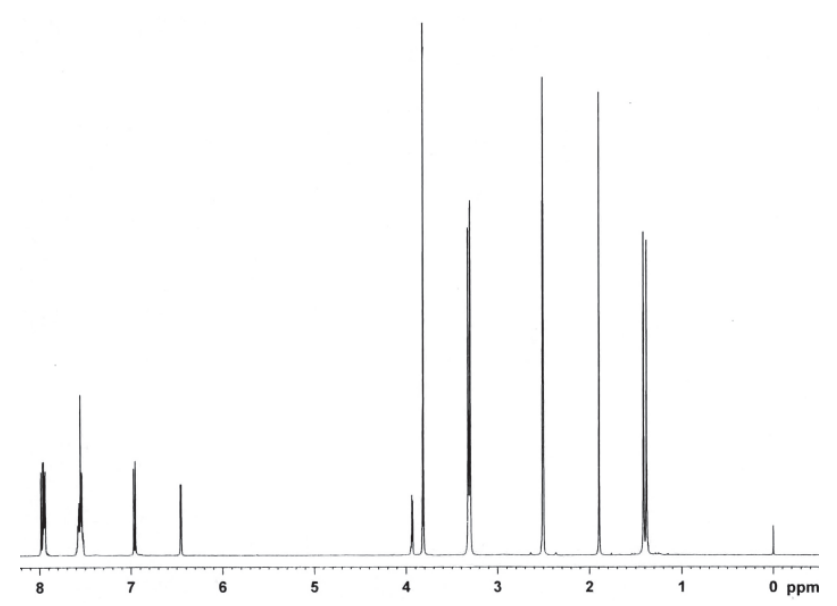

Figure S2. ${ }^{1} \mathrm{H}$ NMR spectra of 1 .

*e-mail: yin_hao_gz@hotmail.com

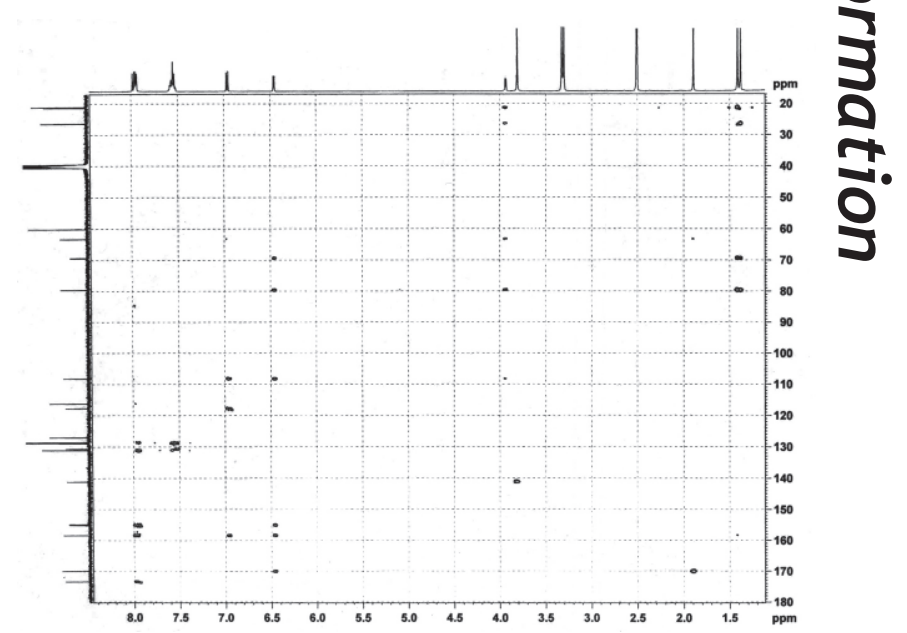

Figure S3. HMBC spectra of 1 .

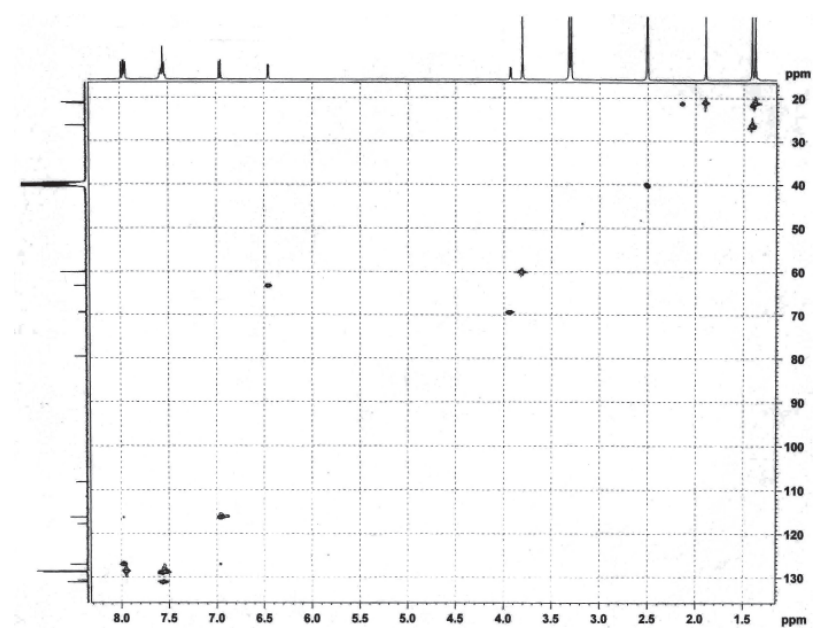

Figure S4. HSQC spectra of 1. 


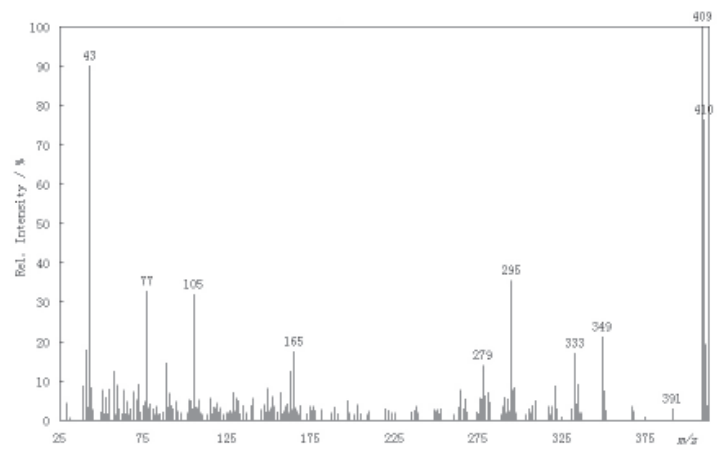

Figure S5. MS spectra of 1.

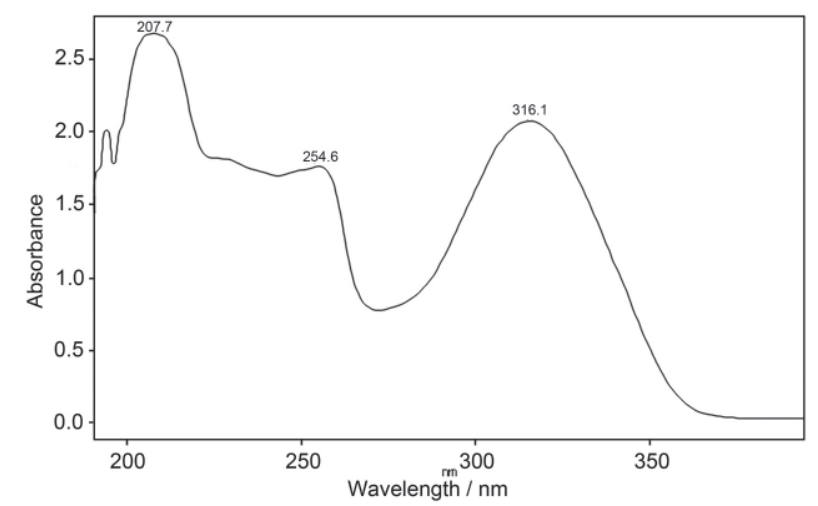

Figure S6. UV spectra of 1.

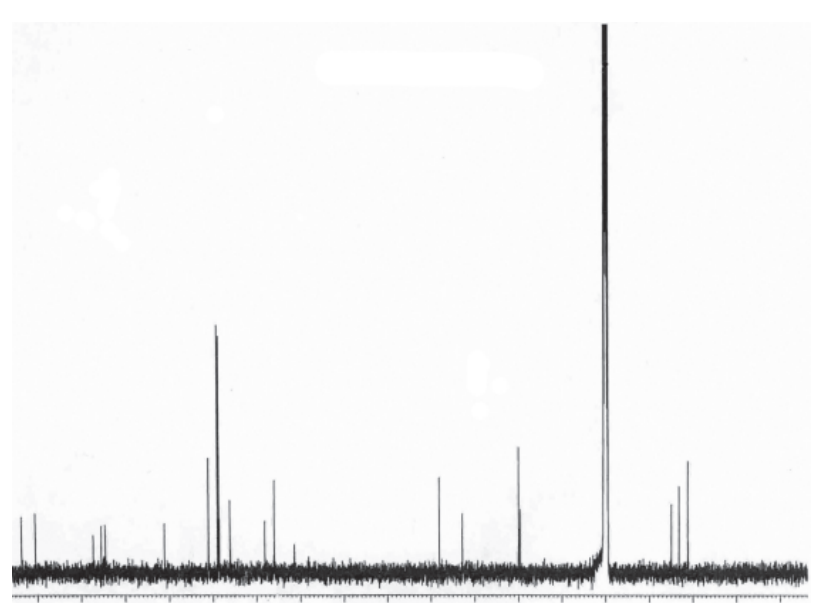

$\begin{array}{llllllllllllllllll}170 & 160 & 150 & 140 & 130 & 120 & 110 & 100 & 90 & 80 & 70 & 60 & 50 & 40 & 30 & 20 & 10 & \text { ppm }\end{array}$ Figure S7. ${ }^{13} \mathrm{C}$ NMR spectra of 2 .

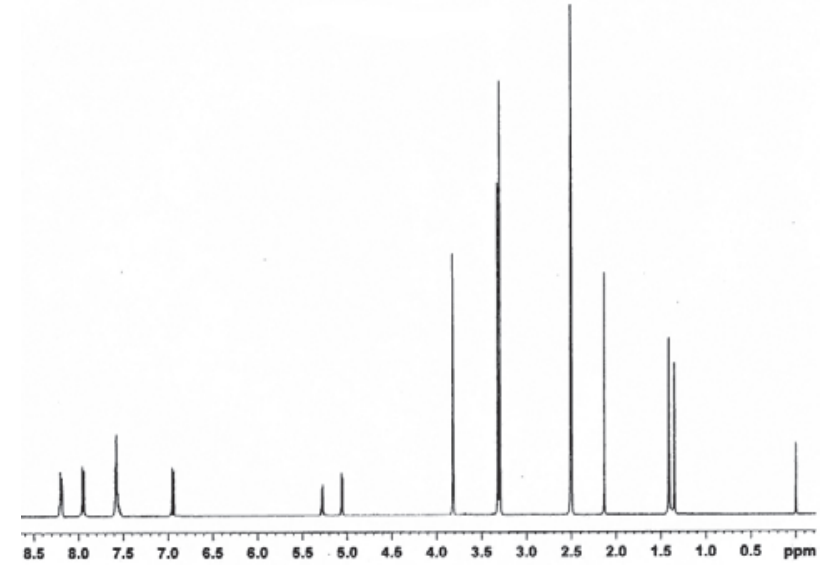

Figure S8. ${ }^{1} \mathrm{H}$ NMR spectra of 2 .

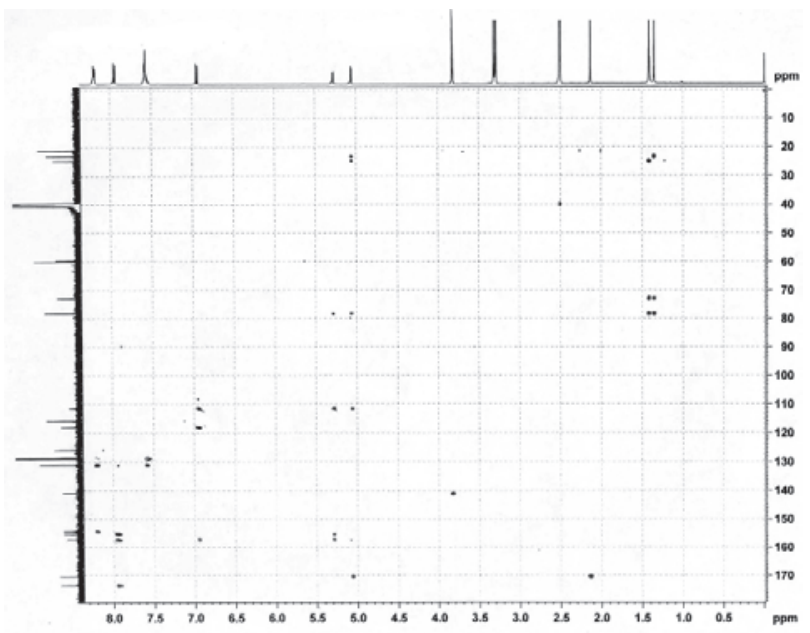

Figure S9. HMBC spectra of 2 .

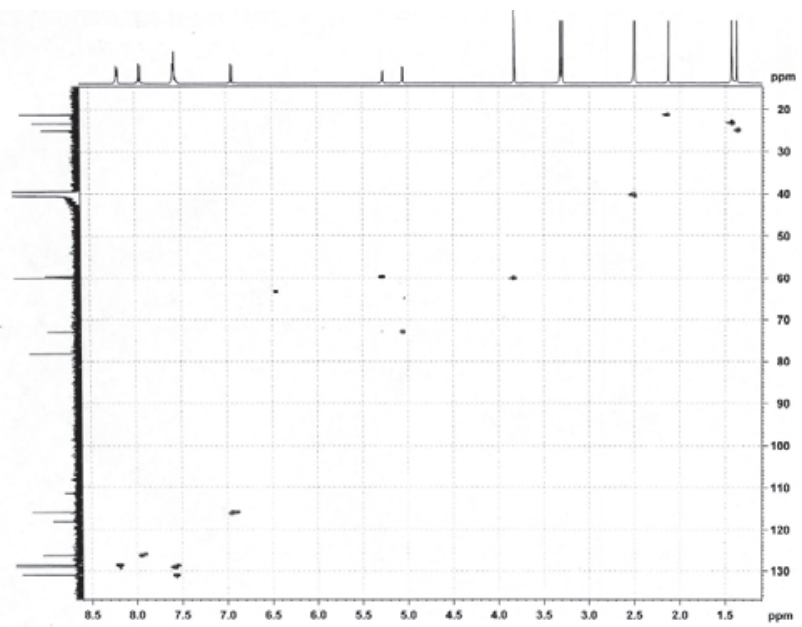

Figure S10. HSQC spectra of 2. 


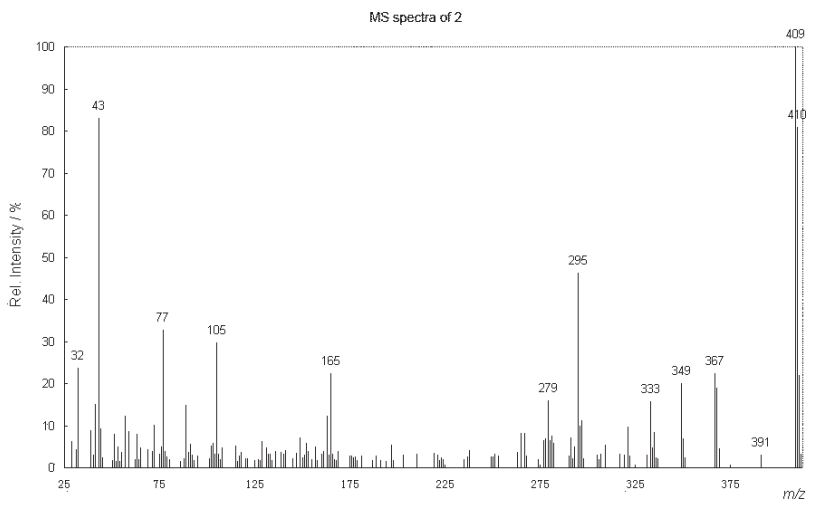

Figure S11. MS spectra of 2.

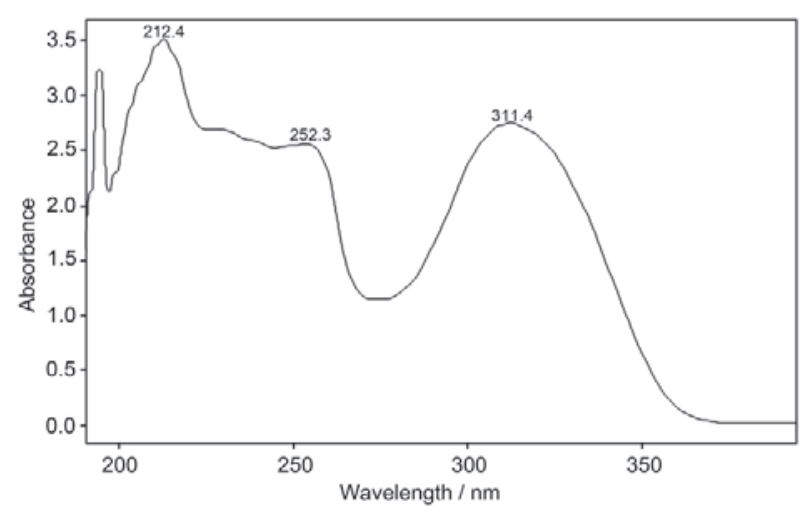

Figure S12. UV spectra of 2. 